\title{
Rare Earth Elements in Coal and Coal Fly Ash
}

\section{Introduction}

The rare earth elements (REEs) are a group of 17 elements sharing similar chemical properties. They include yttrium ( $\mathrm{Y}$, atomic number 39), scandium (Sc, atomic number 21), and the 15 elements of the lanthanide series, atomic numbers 57 (lanthanum, La) to 71 (lutetium, $\mathrm{Lu})$. Because promethium (Pm, atomic number 61) does not occur in the Earth's crust and scandium typically has different geological occurrences from other REEs, they are not discussed further herein.

REEs are, on average, more abundant than precious metals (for example, gold, silver, and platinum), but because of their unique geochemical properties, they do not commonly form economically viable ore deposits (Van Gosen and others, 2014). Nevertheless, REEs are increasingly required for a range of modern applications in defense and renewable energy technologies and in commercial products, primarily as magnets, batteries, and catalysts. The United States currently (2018) produces REEs from a single mine in California, accounting for just 9 percent of global production, whereas 70 percent of global REE production comes from China (Gambogi, 2019; fig. 1). For these reasons, REEs are considered a critical resource, and the U.S. Geological Survey (USGS) has an interest in helping to identify new sources of REEs for domestic production (Hammarstrom and Dicken, 2019).

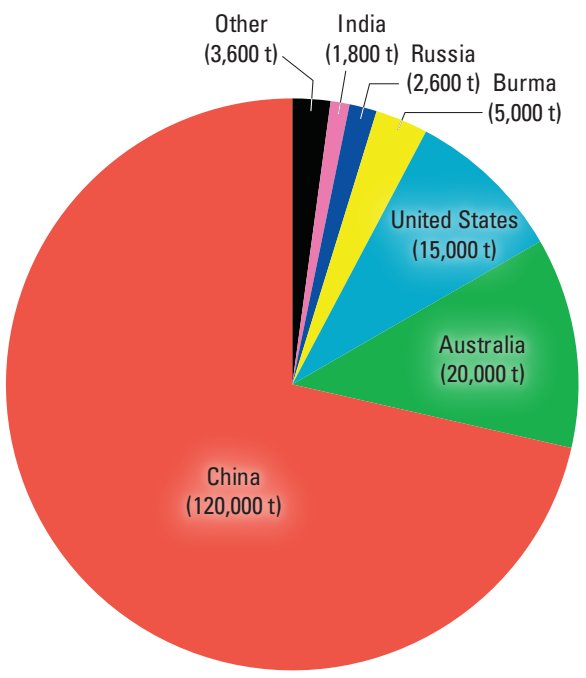

In 2017, coal use accounted for about 30 percent of the electric power generated in the United States (U.S. Energy Information Administration, 2018). Fly ash, produced during the burning of coal, is a fine-grained solid derived from noncombustible constituents of coal, such as clay minerals and quartz. When coal is burned, REEs are retained and enriched in the fly ash and, as a result, fly ash has long been considered a potential resource for REEs (Goldschmidt, 1935; Seredin and Dai, 2012).

The United States has the world's largest coal reserves and, even though gas-fired power generation has increased significantly in the last decade, the United States continues to produce vast quantities of fly ash, about half of which is beneficially reused, primarily in construction materials (American Coal Ash Association, 2017). The remainder is stored, mostly in landfills and impoundments. Thus, annual fly ash production, combined with fly ash already in storage, constitutes a large potential resource (Hower and others, 2017).

Research into how to utilize coal and coal fly ash as sources of REEs is ongoing (National Energy Technology Laboratory, 2018). Viable recovery of REEs from coal and coal ash requires identification of coals and ashes with the highest REE concentrations and development of workable methods for REE extraction and recovery. Understanding how REEs occur within fly ash, described in this fact sheet, is one of the keys to developing possible methods for their recovery.

Figure 1. World mine production of rare earth elements (REEs) by country for 2018 (data from Gambogi, 2019). The total world production for 2018 was 170,000 metric tons $(\mathrm{t})$ : $1 \mathrm{t}=2,204$ pounds. Country totals may not add exactly to the world total because of rounding.

\section{U.S. Geological Survey Research on Rare Earth Elements in Fly Ash}

To better understand how REEs are distributed in coal ash, we investigated the distribution of REEs on a fine scale in 19 coal fly ash samples (table 1 ) having a range of REE contents determined by various workers and compiled by Kolker and others (2017, table 1). The samples include fly ash from U.S. power stations burning bituminous coal from the central Appalachian basin of the eastern United States and from the Illinois basin and subbituminous coal from the Powder River basin in the northern Rocky Mountain region. In addition, we studied four U.S. fly ash samples having mixed or unspecified sources and three samples of fly ash obtained from a Chinese powerplant burning bituminous coal. Fly ash samples from the central Appalachian basin include four samples of ash from the Fire Clay coal of Kentucky, which is known for its REE enrichment (table 1).

Fly ash consists of glasses formed by melting at the high temperatures present in powerplant boilers, together with minerals remaining from coal, such as quartz, and new minerals not present in coal. Before our study, it was poorly understood how REEs are distributed in fly ash. In one hypothesis, suggested by Hower and others (2013) and Taggart and others (2016), REEs from coal enter fly ash glasses. These glasses consist mostly of silicon $(\mathrm{Si})$ and aluminum (Al) and so are called aluminosilicate glasses. To test the hypothesis that REEs enter fly ash glasses, we first identified the various glasses and minerals present in fly ash by using a scanning electron microscope and an electron microprobe, and we produced magnified images and maps of major chemical constituents present (fig. 2). Using this approach, we chose areas of interest for later REE analysis and identified four common glass or mineral constituents in the ash samples: (1) Al-Si aluminosilicate glasses; (2) aluminosilicate glasses that are also enriched in calcium $(\mathrm{Ca})$, iron (Fe), or both $\mathrm{Ca}$ and $\mathrm{Fe}$; (3) iron oxide minerals; and (4) quartz $\left(\mathrm{SiO}_{2}\right)$. 
Table 1. Rare-earth-element (REE) contents of fly ash samples investigated, basins where coals yielding the ash originated, and percentages of critical REEs of the total REE contents.

[Samples are derived from U.S. coals except A-C. Results of analyses by various workers are from the compilation by Kolker and others (2017) and references therein. The contents of REEs are in parts per million (ppm)]

\begin{tabular}{rlrr}
\hline Sample & \multicolumn{1}{c}{ Coal basin } & $\begin{array}{r}\text { Total } \\
\text { REEs } \\
(\mathbf{p p m})\end{array}$ & $\begin{array}{c}\text { Critical } \\
\text { REEs* } \\
(\%)\end{array}$ \\
\hline A & Jungar, Inner Mongolia, China & 192.1 & 28.8 \\
\hline B & Jungar, Inner Mongolia, China & 229.7 & 28.7 \\
\hline C & Jungar, Inner Mongolia, China & 293.5 & 28.3 \\
\hline D & Powder River basin + Appalachian basin mixed & 313.8 & 39.2 \\
\hline E & Powder River basin + Appalachian basin mixed & 365.8 & 37.3 \\
\hline F & Unspecified mixed & 523.6 & 39.7 \\
\hline G & Unspecified mixed & 635.2 & 44.5 \\
\hline H & Central Appalachian basin & 524.5 & 39.5 \\
\hline I & Eastern Interior (Illinois basin) & 366.5 & 39.4 \\
\hline J & Powder River basin & 345.2 & 34.5 \\
\hline K & Central Appalachian basin, Fire Clay coal & $1,534.3$ & 34.7 \\
\hline L & Central Appalachian basin, Fire Clay coal & $1,667.6$ & 36.5 \\
\hline M & Central Appalachian basin & 401.5 & 38.6 \\
\hline N & Eastern Interior (Illinois basin) & 312.1 & 36.2 \\
\hline O & Central Appalachian basin & 563.6 & 38.1 \\
\hline P & Powder River basin & 283.2 & 32.8 \\
\hline Q & Central Appalachian basin, Fire Clay coal & 626.6 & 36.7 \\
\hline R & Central Appalachian basin, Fire Clay coal & 723.4 & 35.1 \\
\hline S & Central Appalachian basin & $1,175.2$ & 38.4 \\
\hline C & & & \\
\hline
\end{tabular}

${ }^{*}$ Critical REEs (listed by increasing atomic number) are yttrium (Y), neodymium (Nd), europium (Eu), terbium ( $\mathrm{Tb}$ ), dysprosium (Dy), and erbium (Er), as defined by Seredin and Dai (2012).

To determine REE contents of fly ash components, we used an instrument called an ion microprobe that produces a primary beam of charged particles (ions) that is directed onto the sample. The Stanford-USGS Sensitive High-Resolution Ion Microprobe with Reverse Geometry (SHRIMP-RG; Bacon and others, 2012) was chosen because it has the appropriate sensitivity (detection limits in the parts per million) and spatial resolution (spot diameter of 15 micrometers) required to select individual fly ash particles for analysis. When the primary ion beam of negatively charged oxygen ions $\left(\mathrm{O}_{2}^{-}\right)$is directed onto a sample, it generates secondary ions of the REEs that are positively charged. These secondary ions are detected by the SHRIMP-RG and quantified by comparing the output to standard reference materials having known REE contents.

\section{Aluminosilicate Glasses}

Two kinds of aluminosilicate glasses were recognized in the fly ash samples investigated, each typically forming glassy cenospheres (hollow spheres; fig. 2). Glasses consisting almost exclusively of $\mathrm{Al}$ and $\mathrm{Si}$ in varying proportions were the most common constituents of the samples investigated. In some samples, aluminosilicate glasses also contained $\mathrm{Ca}$ or $\mathrm{Fe}$, or both $\mathrm{Ca}$ and $\mathrm{Fe}$. To help target possible REE extraction, we were interested in determining if there were differences in the REE contents of these two groups of fly ash glasses.

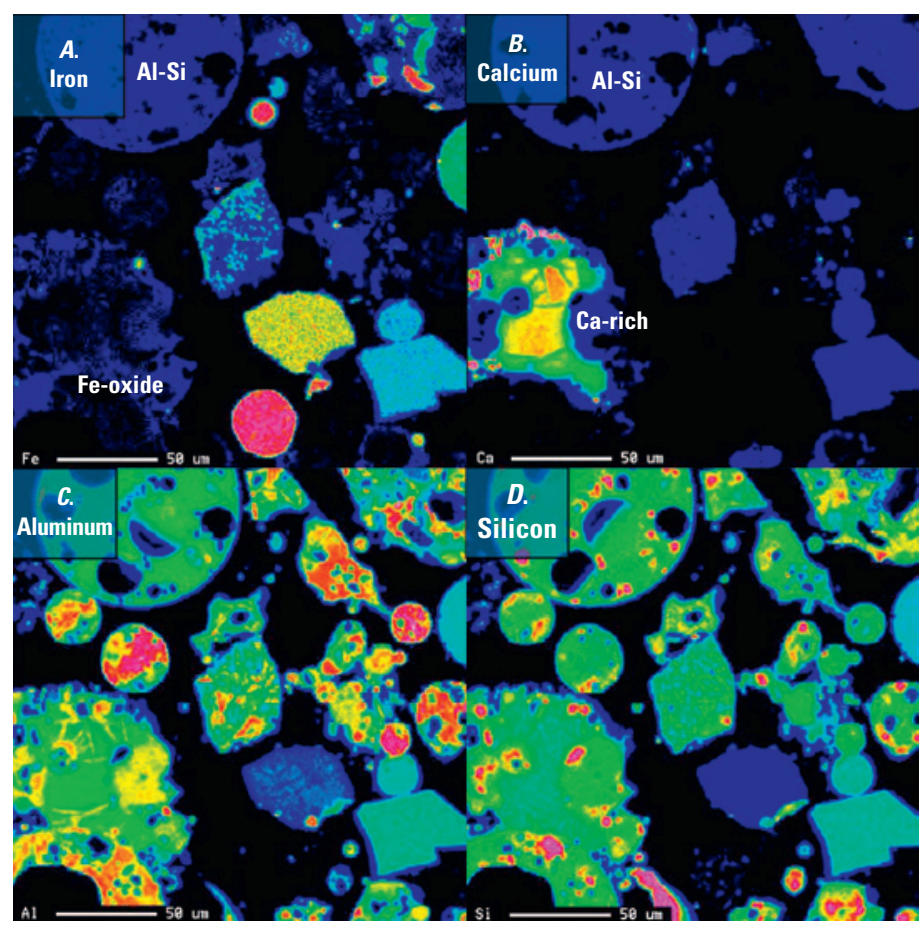

Figure 2. Electron microprobe elemental maps of fly ash sample $\mathrm{G}$ (table 1): $A$, iron (Fe); $B$, calcium (Ca); $C$, aluminum (Al); and $D$, silicon ( $\mathrm{Si}$ ). Labeled features in map $A$ are an Al-Si aluminosilicate cenosphere and Fe-oxide; map $B$ shows Ca-enriched glass. All maps show the same area. Width of the field of view in each map is 225 micrometers $(\mu \mathrm{m})$. False-color maps indicate relative concentrations (reds and yellows indicate higher concentrations, and blues and greens indicate lower concentrations). Black areas are spaces between fly ash grains. From Kolker and others (2017, fig. 4).

In general, REE distributions for Al-Si aluminosilicate glasses are similar to, or slightly lower than, those of the bulk sample, confirming that REEs are partitioned into the glasses during coal combustion (fig. 3). Ca-, Fe-, or Ca- and Fe-enriched aluminosilicate glasses are commonly REE enriched relative to the more common Al-Si glasses (fig. 3), while retaining a similar shape of the REE distribution plot. As the proportion of Si to $\mathrm{Al}$ increases, REE contents decrease, consistent with the REE depletion observed in quartz $\left(\mathrm{SiO}_{2}\right.$; see below).

\section{Fe-0xide Minerals}

As noted above, iron can be incorporated into aluminosilicate glasses during coal combustion. In coal-fired powerplants, temperatures can go from more than 1,500 degrees Celsius to only a few hundred degrees in a matter of seconds (Senior, 2015). This rapid temperature decrease results in rapid nucleation of Fe-oxide minerals within the glass (fig. 4), much as ice crystals nucleate on the surface of a pond when it reaches its freezing point. Previous studies of Fe oxides separated from fly ash show that these contain REEs (Yang and others, 2014). We confirmed this finding by using the SHRIMP-RG. Unlike the aluminosilicate glasses, Fe oxides have more variable REE patterns and overall REE contents, probably because of the variable proportions of $\mathrm{Fe}$ oxides and glass in the spots analyzed (Kolker and others, 2017). 


\section{Quartz}

The REE contents for quartz are consistently much lower than the REE contents of all other fly ash constituents. This REE depletion is expected because of the lack of minor element substitution into the quartz crystal structure (Deer and others, 1963). The REE contents of many quartz grains were below the detection limit of the SHRIMP-RG instrument, and only those with values above the detection limit are shown in figure 3 .

\section{Discussion}

Micrometer-scale REE determinations of fly ash components made by using the Stanford-USGS SHRIMP-RG instrument confirm that REEs are partitioned into aluminosilicate glasses during coal combustion. In coal and in some sedimentary rocks, REEs are concentrated in minerals such as monazite $\left((\mathrm{Ce}, \mathrm{La}, \mathrm{Nd}, \mathrm{Th}) \mathrm{PO}_{4}\right)$, allanite $\left((\mathrm{Ce}, \mathrm{Ca}, \mathrm{Y})_{2}\left(\mathrm{Al}, \mathrm{Fe}^{3+}\right)_{3}\left(\mathrm{SiO}_{4}\right)_{3}(\mathrm{OH})\right)$, zircon $\left(\mathrm{ZrSiO}_{4}\right)$, and xenotime $\left(\mathrm{YPO}_{4}\right)$, all of which occur in trace amounts. These REE minerals are much less common in fly ash than in coal, despite fly ash being greatly REE enriched relative to coal. To explain this, some workers, such as Hood and others (2017), have suggested that REE minerals survive the combustion process but are reduced in size and become more widely distributed due to the thermal shock of the boiler. If this were the case, we would expect to find randomly distributed

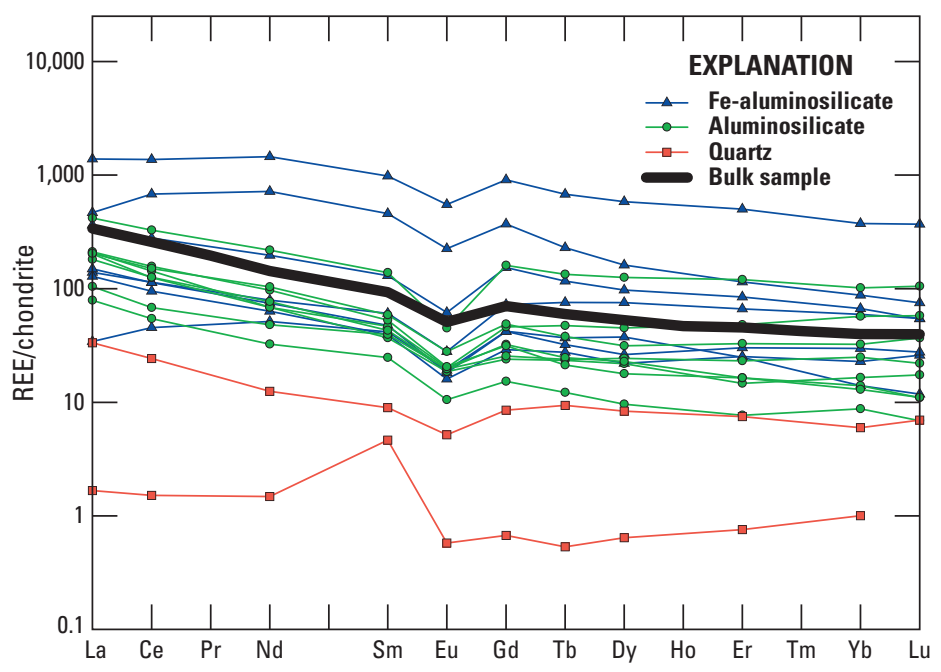

Figure 3. Chondrite-normalized plot showing ion-microprobe (SHRIMP-RG) results for constituents of fly ash sample 0 (table 1) derived from the Fire Clay coal from the central Appalachian basin. By convention, concentrations of rare earth elements (REEs) determined are normalized to concentrations of REEs in chondrites, a group of stony meteorites (see Kolker, 2018, for further discussion). The REE distribution in the bulk sample (heavy solid line) is from Taggart and others (2016). The plot demonstrates the relative enrichment of REEs in iron-bearing aluminosilicate glass (Fe-aluminosilicate) relative to aluminosilicate glasses that lack iron or constituents other than aluminum and silicon. Quartz shows relative REE depletion or the REE concentrations are below detection and are not shown. The unlabeled tick is for promethium (Pm, atomic number 61), which is unstable and was not studied. From Kolker and others (2017, fig. 5).
REE hotspots. Using techniques with micrometer or submicrometer (less than $10^{-6}$ meters) resolution for mapping REE distribution, Stuckman and others (2018) and Hower and others (2017) both recognized localized REE-enriched domains in fly ash, but each of these teams nonetheless considered aluminosilicate glasses to be the dominant host for REEs in fly ash (Stuckman and others, 2018). The overall uniform distribution of REEs in fly ash glasses and the similarity of glass REE distributions to whole-sample distributions suggest that REEs present in REE minerals are redistributed into fly ash glasses during combustion, while these glasses are in the molten state.

\section{Implications for REE Recovery}

Our finding that REEs occur in fly ash glass is both good news and bad news for potential extraction of REEs. The good news is that knowing how REEs occur is helpful to the engineering community working to devise approaches for REE recovery from coal ash. The bad news is that REEs bound in aluminosilicate glasses are likely to be difficult to recover, requiring aggressive approaches such as acid digestion, which may not be viable on a commercial scale. Fly ash is among a range of coal-related products currently under consideration as potential REE sources. In some cases, such as in some low-rank coals, greater extractability of REEs may offset the fact that these coals have much lower overall REE contents than does fly ash (Laudal and others, 2018). The present study shows that REEs in fly ash glasses, the most abundant constituent of coal fly ash, should be targeted in devising approaches for extraction and concentration of REEs. Our results show that, if possible, Fe-oxides should be included and quartz should be excluded in processing fly ash for REE recovery.

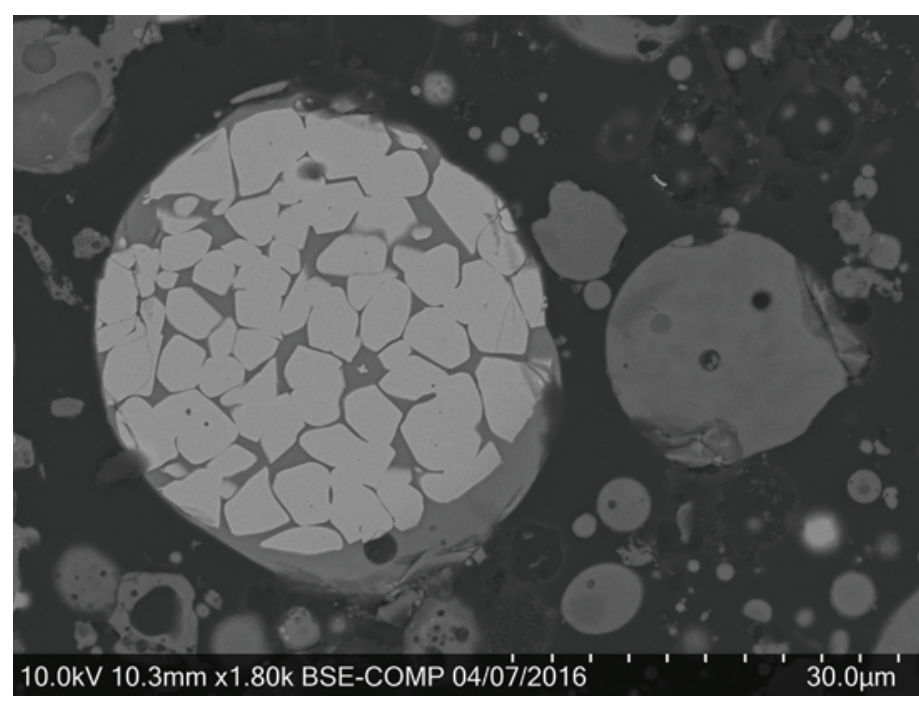

Figure 4. Backscattered electron image from a scanning electron microscope showing iron oxides (bright patches) within a matrix of aluminosilicate glass (darker interstices) in sample M, fly ash derived from coal from the central Appalachian basin (table 1). Width of field of view is approximately 70 micrometers $(\mu \mathrm{m})$. 


\section{References Cited}

American Coal Ash Association, 2017, 2016 coal combustion product $(\mathrm{CCP})$ production and use survey report: American Coal Ash Association report, accessed June 15, 2018, at https://www.acaa-usa.org/Portals/9/Files/PDFs/2016-SurveyResults.pdf.

Bacon, C.R., Grove, M., Vazquez, J.A., and Coble, M.A., 2012, The Stanford-U.S. Geological Survey SHRIMP ion microprobe-A tool for micro-scale chemical and isotopic analysis: U.S. Geological Survey Fact Sheet 2012-3067, 4 p. [Also available at https://pubs.usgs.gov/fs/2012/3067/.]

Deer, W.A., Howie, R.A., and Zussman, J., 1963, Framework silicates, v. 4 of Rock-forming minerals: New York, John Wiley and Sons, Inc., 435 p.

Gambogi, J., 2019, Rare earths: U.S. Geological Survey Mineral Commodity Summaries 2019, p. 132-133, accessed April 8, 2019, at https://minerals.usgs.gov/minerals/pubs/commodity/ rare_earths/mcs-2019-raree.pdf.

Goldschmidt, V.M., 1935, Rare elements in coal ashes: Industrial and Engineering Chemistry, v. 27, no. 9, p. 1100-1102. [Also available at https://doi.org/10.1021/ie50309a032.]

Hammarstrom, J.M., and Dicken, C.L., 2019, Focus areas for data acquisition for potential domestic sources of critical minerals - Rare earth elements, chap. A of U.S. Geological Survey, Focus areas for data acquisition for potential domestic sources of critical minerals: U.S. Geological Survey OpenFile Report 2019-1023, 11 p., accessed April 8, 2019, at https://doi.org/10.3133/ofr20191023A.

Hood, M.M., Taggart, R.K., Smith, R.C., Hsu-Kim, H., Henke, K.R., Graham, U., Groppo, J.G., Unrine, J.M., and Hower, J.C., 2017, Rare earth element distribution in fly ash derived from the Fire Clay coal, Kentucky: Coal Combustion and Gasification Products, v. 9, p. 22-33. [Also available at https://doi. org/10.4177/CCGP-D-17-00002.1.]

Hower, J.C., Groppo, J.G., Henke, K.R., Graham, U.M., Hood, M.M., Joshi, P., and Preda, D.V., 2017, Ponded and landfilled fly ash as a source of rare earth elements from a Kentucky power plant: Coal Combustion and Gasification Products, v. 9, p. 1-21. [Also available at https://doi.org/10.4177/CCGPD-17-00003.1.]

Hower, J.C., Groppo, J.G., Joshi, P., Dai, S., Moecher, D.P., and Johnston, M.N., 2013, Location of cerium in coal combustion fly ashes - Implications for recovery of lanthanides: Coal Combustion and Gasification Products, v. 5, p. 73-78. [Also available at https://doi.org/10.4177/CCGP-D13-00007.1.]

Kolker, A., 2018, Topics in coal geochemistry-Short course: U.S. Geological Survey Open-File Report 2018-1145, 31 p., and appendix 2 in a separate file, accessed October 17, 2018, at https://doi.org/10.3133/ofr20181145.

Kolker, A., Scott, C., Hower, J.C., Vazquez, J.A., Lopano, C.L., and Dai, S., 2017, Distribution of rare earth elements in coal combustion fly ash, determined by SHRIMP-RG ion microprobe: International Journal of Coal Geology, v. 184, p. 1-10. [Also available at https://doi.org/10.1016/j.coal.2017.10.002.]
Laudal, D.A., Benson, S.A., Addleman, R.S., and Palo, D., 2018, Leaching behavior of rare earth elements in Fort Union lignite coals of North America: International Journal of Coal Geology, v. 191, p. 112-124. [Also available at https://doi. org/10.1016/j.coal.2018.03.010.]

National Energy Technology Laboratory, 2018, Rare earth elements from coal and coal by-products: National Energy Technology Laboratory website, accessed October 2018 at https://www.netl.doe.gov/research/coal/rare-earth-elements.

Senior, C., 2015, Mercury behavior in coal combustion systems, chap. 7 of Granite, E.J., Pennline, H.W., and Senior, C., eds., Mercury control for coal-derived gas streams: New York, Wiley-VCH, p. 111-131. [Also available at https://doi. org/10.1002/9783527658787.ch7.]

Seredin, V.V., and Dai, S., 2012, Coal deposits as potential alternative sources for lanthanides and yttrium: International Journal of Coal Geology, v. 94, p. 67-93. [Also available at https://doi.org/10.1016/j.coal.2011.11.001.]

Stuckman, M.Y., Lopano, C.L., and Granite, E.J., 2018, Distribution and speciation of rare earth elements in coal combustion by-products via synchrotron microscopy and spectroscopy: International Journal of Coal Geology, v. 195, p. 125-138. [Also available at https://doi.org/10.1016/j.coal.2018.06.001.]

Taggart, R.K., Hower, J.C., Dwyer, G.S., and Hsu-Kim, H., 2016, Trends in the rare earth element content of U.S.-based coal combustion fly ashes: Environmental Science and Technology, v. 50, no. 11, p. 5919-5926. [Also available at https://doi.org/10.1021/acs.est.6b00085.]

U.S. Energy Information Administration, 2018, Total electric power industry summary statistics, 2017 and 2016, table 1.1 of U.S. Energy Information Administration, Electric power annual 2017: U.S. Energy Information Administration, accessed October 2018 at https://www.eia.gov/electricity/ annual/html/epa_01_01.html.

Van Gosen, B.S., Verplanck, P.L., Long, K.R., Gambogi, J., and Seal, R.R., II, 2014, The rare-earth elements-Vital to modern technologies and lifestyles: U.S. Geological Survey Fact Sheet 2014-3078, 4 p., accessed September 2018 at https://doi. org/10.3133/fs20143078.

Yang, J., Zhao, Y., Zyryanov, V., Zhang, J., and Zheng, C., 2014, Physical-chemical characteristics and elements enrichment of magnetospheres from coal fly ashes: Fuel, v. 135, p. 15-26. [Also available at https://doi.org/10.1016/j.fuel.2014.06.033.]

\section{-By Clint Scott and Allan Kolker}

For more information, contact

Science Center Director

Eastern Energy Resources Science Center \&

Eastern Mineral \& Environmental Resources Science Center

12201 Sunrise Valley Drive

Mail Stop 954

Reston, VA 20192-0002

Acquisition of SHRIMP-RG data was supported in part by a Technical Assistance Agreement between the USGS and the University of Kentucky, with funding from U.S. Department of Energy contract DE-FE0027167.

Banner photograph by Pixabay

(https://www.pexels.com/photo/

black-charcoals-48884/).

ISSN 2327-6932 (online) https://doi.org/10.3133/fs20193048 